\title{
PENERAPAN METODE DEMONSTRASI MELALUI KEGIATAN MERONCE UNTUK MENINGKATKAN PERKEMBANGAN MOTORIK HALUS
}

\author{
Ni Md. Ari Wulandari ${ }^{1}$, Kt. Pudjawan² \\ 1,2Jurusan Pendidikan Guru Pendidikan Anak Usia Dini, FIP \\ Universitas Pendidikan Ganesha \\ Singaraja, Indonesia
}

Email: dekwulan68@gmail.com¹, ketutpudjawan@gmail.com²,

\begin{abstract}
Abstrak
Penelitian ini adalah penelitian tindakan kelas yang bertujuan untuk mengetahui peningkatkan perkembangan motorik halus melalui penerapan metode demonstrasi melalui kegiatan meronce. Penelitian tindakan kelas ini menggunakan 2 siklus. Subjek penelitian ini adalah anak kelompok B1 TK Kartika VII-3 Singaraja yang berjumlah 19 orang. Instrument penelitian ini menggunakan lembar observasi. Data hasil penelitian dianalisis menggunakan metode analisis statistik deskriptif dan metode analisis deskriptif kuantitatif. Hasil analisis data menunjukkan bahwa terjadi peningkatan perkembangan motorik halus dari penerapan metode demonstrasi melalui kegiatan meronce mencapai $22,43 \%$. Pada siklus I sebesar $59,58 \%$ yang berada pada kriteria rendah mengalami peningkatan pada siklus II menjadi $82,01 \%$ tergolong kriteria tinggi. Dengan demikian dapat disimpulkan bahwa penerapan metode demonstrasi melalui kegiatan meronce dapat meningkatkan perkembangan motorik halus pada anak kelompok B1 TK Kartika VII-3 Singaraja.
\end{abstract}

Kata-kata kunci: Metode demonstrasi, kegiatan meronce, motorik halus

\begin{abstract}
This research purpose to find out the improvement of fine motor skill development through the applying demontration method by meronce activities to the children in group B1 at TK Kartika VII-3 Singaraja. Type of this research was classroom action research (CAR) which implemented two cycles. Subject of this research were 19 children of group B1 TK Kartika VII-3 Singaraja. Than the research data about fine motor skill development collected by using observation method. The data were analyzed by using descriptive statistics method, and descriptive quantitative analysis method. The result of analysis data shows there is an improvement of fine motor skill development when applying demontration method assisted by meronce activities raearches $22,43 \%$. In the first cycle it's reaches $59,58 \%$ which is low criteria increase in the second cycle to $82,01 \%$ which at high criteria. Thus it can be concluded that applying demontration method assisted by meronce activities can improve the fine motor skill development of the children in group B1 at TK Kartika VII-3 Singaraja.
\end{abstract}

Keywords: Demonstration method, meronce activities, fine motor.

\section{Pendahuluan}

Hakikat pendidikan tidak akan terlepas dari hakikat manusia, sebab subjek utama pendidikan adalah manusia. Pendidikan merupakan hal yang sangat penting dalam meningkatkan kecerdasan bangsa, melalui pendidikan manusia akan mempunyai daya pikir bagaimana cara merubah kehidupan dari yang kurang baik menjadi lebih baik lagi. Maka dari 
itu, untuk mencapai tujuan tersebut maka pendidikan sejak usia dini sangatlah penting untuk perkembangan anak. Dalam Peraturan Menteri Pendidikan dan Kebudayaan Republik Indonesia, sesuai dengan Undang-undang Nomor 146 Tahun 2014 tentang Kurikulum 2013 Pendidikan Anak Usia Dini, bahwa:

Pendidikan Anak Usia Dini, yang selanjutnya disingkat PAUD, merupakan suatu upaya pembinaan yang ditujukan kepada anak sejak lahir sampai dengan usia 6 (enam) tahun yang dilakukan melalui pemberian rangsangan pendidikan untuk membantu pertumbuhan dan perkembangan jasmani dan rohani agar anak memiliki kesiapan dalam memasuki pendidikan lebih lanjut.

Usia dini adalah usia yang sangat berharga bagi anak, di mana pada usia dini merupakan usia keemasan (golden age) yang merupakan dasar bagi masa depan anak. Oleh karena itu, para pendidik maupun orang tua sangat berperan penting dalam mendidik dan merangsang tumbuh kembang anak. Anak usia dini bebas mengekspresikan kemampuannya dan bebas bereksplorasi sesuai perkembangannya. Dalam hal ini para guru dan orang tua harus bekerja sama dalam mengembangkan kemampuan anak. Setiap anak mempunyai karakteristik yang berbeda-beda, Pada dasarnya anak usia dini memiliki potensi kemampuan motorik,namun setiap anak memiliki kemampuan yang berbeda-beda, seperti halnya pada anak kelompok B1 di TK Kartika VII-3 Singaraja. Berdasarkan hasil observasi Di TK Kartika pada anak kelompok B1 diemukan permasalahan pada kemampuan motorik halusnya. Dapat dilihat pada pembelajaran yang berlangsung, permasalahan sebagaian besar anak adalah belum mampu memegang pensil dengan benar, beberapa anak belum mampu menggunting kertas secara sederhana, anak belum mampu menyobek kertas dan menempelnya secara sederhana ini dikarenakan tangan anak masih kaku dan kurang lentur.

Berdasarkan latar belakang diatas, maka permasalahan yang dapat dirumuskan adalah sebagai berikut. apakah penerapan metode demonstrasi melalui kegiatan meronce dapat meningkatkan perkembangan motorik halus pada anak kelompok B1 TK Kartika VII-3 Singaraja tahun pelajaran 2018/2019?.

Berdasarkan rumusan masalah yang telah diuraikan sebelumnya maka adapun tujuan dari penelitian ini adalah sebagai berikut. untuk mengetahui peningkatan perkembangan motorik halus saat menerapkan metode demonstrasi melalui kegiatan meronce pada anak kelompok B1 TK Kartika VII-3 Singaraja tahun pelajaran 2018/2019.

Penelitian tindakan kelas ini dilaksanakan pada kelompok B1 TK Kartika VII-3 Singaraja. Penelitian ini dilaksanakan pada semester I Tahun Pelajaran 2018/2019 dengan mengambil tempat di TK Kartika VII-3 Singaraja. Aspek perkembangan yang ingin dicapai adalah perkembangan motorik halus.

Metode pembelajaran merupakan hal penting yang harus digunakan oleh seorang guru dalam proses pembelajaran. Suatu pembelajaran akan menyenangkan dan dapat menarik minat siswa untuk belajar apabila metode pembelajaran yang digunakan guru menarik dan bervariasi. Menurut Agung (2012:1) "Metode berasal dari kata methodos. Secara etimologis methodos berasal dari akar kata metha dan hodos. Metha artinya dilalui dan hodos berarti jalan. Metode ialah jalan atau cara yang harus dilalui untuk mencapai suatu tujuan". Salah satu metode yang tepat dalam kegiatan pembelajaran untuk meningkatkan motorik halus anak adalah metode demonstrasi. Metode Demonstrasi adalah metode mengajar yang menggunakan peragaan untuk memperjelas suatu pengertian atau untuk memperlihatkan pada seluruh siswa tentang suatu proses atau suatu petunjuk untuk melakukan sesuatu. Metode demonstrasi merupakan salah satu metode yang dapat membantu siswa memperjelas suatu kegiatan pembelajaran dan juga dapat meningkatkan daya pikir anak terutama dalam kemampuan mengenal, mengingat, dan berpikir baik kritis maupun kreatif.

Metode pembelajaran atau metode belajar demonstrasi merupakan metode mengajar dengan menggunakan alat peraga, kejadian, aturan dan urutan melakukan kegiatan, baik secara langsung maupun melalui penggunaan media pengajaran yang relevan dengan pokok bahasan atau materi yang sedang disajikan. Adapun pengertian metode demonstrasi menurut Latif (2013:114) "Perolehan pengalaman belajar yang dirancang secara khusus untuk 
menunjukkan, mengerjakan, dan menjelaskan suatu objek atau proses dari suatu peristiwa yang sedang dilakukan merupakan salah satu metode bermain yang disebut dengan demonstrasi". Selain itu Subini (2012:103) juga menjelaskan "Metode demonstrasi adalah metode pembelajaran di mana guru menjelaskan suatu materi pelajaran dengan memperlihatkan suatu proses atau cara kerja yang berkaitan dengan materi”. Sedangkan Yulianti (2010:38) menyatakan "Metode demonstrasi merupakan cara untuk menunjukkan dan menjelaskan cara-cara mengerjakan sesuatu". Lebih lanjut Sanjaya (2008:152) menyatakan:

Metode demonstrasi adalah metode penyajian pelajaran dengan memperagakan dan mempertunjukkan kepada siswa tentang suatu proses, situasi, atau benda tertentu, baik sebenarnya atau hanya sekedar tiruan. Sebagai metode penyajian, demonstrasi tidak terlepas dari penjelasan secara lisan oleh guru. Walaupun dalam proses demonstrasi peran siswa hanya sekedar memerhatikan, akan tetapi demonstrasi dapat menyajikan bahan pelajaran lebih konkret. Dalam strategi pembelajaran, demonstrasi dapat digunakan untuk mendukung keberhasilan strategi pembelajaran ekspositori dan inkuiri.

Menurut Djamarah (2006:90) menyatakan:

Metode demonstrasi adalah cara penyajian pelajaran dengan memperagakan atau mempertunjukkan kepada siswa suatu proses, situasi, atau benda tertentu yang sedang dipelajari, baik sebenarnya ataupun tiruan, yang sering disertai dengan penjelasan lisan. Dengan metode demonstrasi, proses penerimaan siswa terhadap pelajaran akan lebih berkesan secara mendalam, sehingga membentuk pengertian dengan baik dan sempurna. Juga siswa dapat mengamati dan memperhatikan apa yang diperlihatkan selama pelajaran berlangsung.

Jadi dapat disimpulkan bahwa pengertian metode demonstrasi adalah cara memperagakan dan mempertunjukkan kepada siswa tentang suatu proses, situasi, atau benda tertentu dalam suatu kegiatan pembelajaran.

Metode demonstrasi mempunyai manfaat penting untuk mengembangkan kegiatan pembelajaran anak usia dini. Adapun manfaat metode demonstrasi adalah metode demonstrasi dipilih oleh guru dalam kegiatan mengajar karena beberapa manfaat yaitu perhatian anak dapat lebih dipusatkan, proses belajar anak lebih terarah pada materi yang sedang dipelajari, pengalaman dan kesan sebagai hasil pembelajaran lebih melekat. Melihat ketiga manfaat tersebut anak dapat mempelajari secara langsung dan jelas melalui pengamatannya melalui penerapan metode demonstrasi. Metode demonstrasi juga dapat membuat anak tertarik terhadap pembelajaran yang diberikan oleh guru, selain anak dapat belajar dengan baik, guru juga lebih mudah memberi contoh kegiatan pembelajaran kepada anak. Menurut Subini (2012:103) "Manfaat metode demonstrasi adalah membantu anak didik dalam memahami jalannya suatu proses atau cara kerja suatu benda melalui pengamatan yang nyata (konkrit)".

Selain itu menurut Djamarah (2006:90) bahwa:

Manfaat metode demonstrasi adalah anak mendapatkan gambaran yang lebih jelas tentang hal-hal yang berhubungan dengan proses mengatur sesuatu, proses membuat sesuatu, proses bekerjanya sesuatu, proses mengerjakan atau menggunakannya, komponen-komponen yang membentuk sesuatu, membandingkan suatu cara dengan cara lain, dan untuk mengetahui atau melihat kebenaran sesuatu.

Jadi dapat disimpulkan bahwa manfaat dari metode demonstrasi adalah membantu anak didik atau siswa untuk lebih memahami dan lebih mengerti tentang kegiatan pembelajaran yang disampaikan oleh guru melalui proses membuat sesuatu dan proses bekerjanya sesuatu.

Subjek dalam penelitian ini adalah anak-anak TK Kartika VII-3 Singaraja sebanyak 19 orang terdiri dari 9 anak laki-laki dan 10 anak perempuan pada kelompok B1 semester I TK Kartika VII-3 Singaraja Tahun Pelajaran 2018/2019.

Adapun objek penelitian ini adalah 1) Variabel bebas: Metode demonstrasi melalui kegiatan meronce, 2) Variabel terikat: Perkembangan motorik halus.

Penelitian ini dirancang dalam bentuk penelitian tindakan kelas. Penelitian tindakan kelas merupakan prosedur penelitian di kelas yang dirancang untuk menanggulangi masalah 
nyata yang dialami guru berkaitan dengan siswa di kelas itu. Penelitian ini dirancang dalam dua siklus. "Tiap siklus terdiri atas empat tahapan yaitu: perencanaan, pelaksanaan tindakan, observasi/evaluasi dan refleksi" (Arikunto, 2012).

Selanjutnya menurut Arikunto (2012:3) "Penelitian tindakan kelas merupakan suatu pencermatan terhadap kegiatan belajar berupa sebuah tindakan, yang sengaja dimunculkan dan terjadi dalam sebuah kelas secara bersama".

Sebagaimana telah dijelaskan sebelumnya PTK terdiri atas rangkaian empat kegiatan yang dilakukan dalam siklus berulang. Empat kegiatan utama yang ada pada setiap siklus, yaitu perencanaan, tindakan, pengamatan, dan refleksi.

Untuk lebih memudahkan guru dalam melaksanakan kegiatan pembelajaran maka sangat diperlukan sintaks suatu pembelajaran, sintaks merupakan langkah-langkah yang dapat mempermudah untuk melaksanakan pembelajaran. Metode demonstrasi mempunyai sintaks yang akan membantu mempermudah jalannya kegiatan pembelajaran menggunakan media kegiatan meronce.

Menurut Aqib (2013:29) bahwa:

Langkah-langkah demonstrasi adalah 1) guru menyampaikan tujuan pembelajaran, 2) guru menyajikan gambaran sekilas materi yang akan disampaikan, 3) siapkan bahan atau alat yang diperlukan, 4) menunjukkan salah seorang siswa untuk mendemonstrasikan sesuai scenario yang telah disiapkan, 5) seluruh siswa memerhatikan demonstrasi dan menganalisa, 6) tiap siswa atau kelompok mengemukakan hasil analisisnya dan juga pengalaman siswa didemonstrasikan, dan 7) guru membuat kesimpulan.

Setiap metode pembelajaran mempunyai beberapa kelebihan dan kekurangan, sebagai suatu metode pembelajaran, metode demonstrasi memiliki beberapa kelebihan, di antaranya menurut pendapat Djamarah (2006:91) menyatakan:

1) Dapat membuat pengajaran menjadi lebih jelas dan lebih konkret, sehingga menghindari verbalisme (pemahaman secara kata-kata atau kalimat), 2) siswa lebih mudah memahami apa yang dipelajari, 3) proses pengajaran lebih menarik, 4) Siswa dirangsang untuk aktif mengamati, menyesuaikan antara teori dengan kenyataan, dan mencoba melakukannya sendiri.

Sedangkan menurut Iru (2012:31) bahwa:

Keunggulan metode demonstrasi adalah: a) siswa-siswa dapat memahami bahan pelajaran sesuai dengan objek yang sebenarnya, b) dapat mengembangkan rasa ingin tahu siswa, c) dapat melakukan pekerjaan berdasarkan proses yang sistematis, d) dapat mengetahui hubungan yang struktural atau urutan objek, dan e) dapat melakukan perbandingan dari beberapa objek.

Dengan demikian dapat disimpulkan bahwa kelebihan dari metode demonstrasi adalah dapat membuat pembelajaran lebih jelas sehingga anak lebih memahami kegiatan pembelajaran kemudian anak aktif dan tertarik mencoba melakukan sendiri dalam pembelajaran.

Di samping beberapa kelebihan, metode demonstrasi juga memiliki beberapa kekurangan, di antaranya, 1) Metode demonstrasi memerlukan persiapan yang lebih matang, sebab tanpa persiapan yang memadai demonstrasi bisa gagal sehingga dapat menyebabkan metode ini tidak efektif lagi. Bahkan sering terjadi untuk menghasilkan pertunjukkan suatu proses tertentu, guru harus beberapa kali mencobanya terlebih dahulu, sehingga dapat memakan waktu yang banyak, 2) Demonstrasi memerlukan peralatan, bahan-bahan, dan tempat yang memadai yang berarti penggunaan metode ini memerlukan pembiayaan yang lebih mahal dibandingkan dengan ceramah, 3) Demonstrasi memerlukan kemampuan dan keterampilan guru yang khusus, sehingga guru dituntut untuk bekerja lebih profesional. Di samping itu demonstrasi juga memerlukan kemauan dan motivasi guru yang bagus untuk keberhasilan proses pembelajaran siswa. Lebih lanjut menurut Djamarah (2006:91) bahwa:

Kekurangan metode demonstrasi yaitu 1) metode ini memerlukan keterampilan guru secara khusus, karena tanpa ditunjang dengan hal itu, pelaksanaan demonstrasi akan tidak efektif, 2) Fasilitas seperti peralatan, tempat, dan biaya yang memadai tidak selalu tersedia dengan baik, 
3) demonstrasi memerlukan kesiapan dan perencanaan yang matang di samping memerlukan waktu yang cukup panjang, yang mungkin terpaksa mengambil waktu atau jam pelajaran lain.

Dengan demikian dapat disimpulkan bahwa kelemahan dari metode demonstrasi adalah memerlukan keterampilan khusus dari guru agar pelaksanaannya efektif dan memerlukan perencanaan yang matang agar tidak memerlukan waktu yang panjang.

Dalam bahasa Arab, media adalah perantara atau pembawa pesan dari pengirim kepada penerima pesan. Menurut Gerlach dan Ely (dalam Latif, 2013:151) "bila dipahami secara garis besar media adalah manusia, materi, atau kejadian yang membangun kondisi yang membuat siswa mampu memperoleh pengetahuan keterampilan, atau sikap".

Dengan demikian dapat disimpulkan bahwa media pembelajaran adalah sarana yang digunakan guru untuk menyampaikan pesan atau kegiatan pembelajaran kepada anak untuk mencapai tujuan pembelajaran.

Meronce merupakan kagiatan yang menyenangkan untuk anak, menurut Sumanto (2005:159) bahwa "meronce merupakan cara pembuatan benda hias atau benda pakai yang dilakukan dengan menyusun bagian-bagian bahan berlubang atau yang sengaja dilubangi memakai bantuan benang, tali dan sejenisnya".

Menurut (Sumantri, 2005:151) meronce adalah "salah satu contoh kegiatan pengembangan motorik halus di TK, kegiatan menguntai dengan membuat untaian dari bahanbahan yang berlubang, disatukan dengan tali atau benang".

\section{Metode}

Penelitian tindakan kelas ini dilaksanakan pada kelompok B1 TK Kartika VII-3 Singaraja. Penelitian ini dilaksanakan pada semester I Tahun Pelajaran 2018/2019 dengan mengambil tempat di TK Kartika VII-3 Singaraja. Aspek perkembangan yang ingin dicapai adalah perkembangan motorik halus.

Subjek dalam penelitian ini adalah anak-anak TK Kartika VII-3 Singaraja sebanyak 19 orang terdiri dari 9 anak laki-laki dan 10 anak perempuan pada kelompok B1 semester I TK Kartika VII-3 Singaraja Tahun Pelajaran 2018/2019.

Adapun objek penelitian ini adalah 1) Variabel bebas: Metode demonstrasi melalui kegiatan meronce, 2) Variabel terikat: Perkembangan motorik halus.

Penelitian ini dirancang dalam bentuk penelitian tindakan kelas. Penelitian tindakan kelas merupakan prosedur penelitian di kelas yang dirancang untuk menanggulangi masalah nyata yang dialami guru berkaitan dengan siswa di kelas itu. Penelitian ini dirancang dalam dua siklus. "Tiap siklus terdiri atas empat tahapan yaitu: perencanaan, pelaksanaan tindakan, observasi/evaluasi dan refleksi" (Arikunto, 2012).

Selanjutnya menurut Arikunto (2012:3) Penelitian tindakan kelas merupakan suatu pencermatan terhadap kegiatan belajar berupa sebuah tindakan, yang sengaja dimunculkan dan terjadi dalam sebuah kelas secara bersama".

Sebagaimana telah dijelaskan sebelumnya PTK terdiri atas rangkaian empat kegiatan yang dilakukan dalam siklus berulang. Empat kegiatan utama yang ada pada setiap siklus, yaitu perencanaan, tindakan, pengamatan, dan refleksi. Tiap siklus terdiri atas empat tahapan yaitu perencanaan, pelaksanaan tindakan, observasi/evaluasi dan refleksi" (Arikunto dkk, 2012).

Metode pengumpulan data dalam penelitian ini adalah metode observasi. Observasi merupakan pengamatan yang dilakukan secara langsung untuk mengolah data perkembangan motorik halus anak. Menurut Yus (2012:74) menyatakan observasi atau pengamatan merupakan proses pengumpulan data dengan menggunakan alat indra. Data yang direkam perlu segera dicatat atau direkam. Observasi merupakan penilaian yang dilakukan dengan mengamati perilaku dan aktivitas anak dalam suatu waktu atau kegiatan. Jadi dapat disimpulkan bahwa observasi adalah cara memperoleh data dengan melakukan pengamatan secara langsung. Setelah data yang diperlukan dalam penelitian ini terkumpul, maka dilakukan analisis data. Dalam menganalisis data digunakan metode analisis statistik deskriptif, dan metode analisis deskriptif kuantitatif. Metode analisis statistik deskriptif digunakan untuk 
mendeskripsikan data penelitian, hasil dari analisa data secara deskriptif disajikan dalam bentuk tabel distribusi frekuensi, mean, median, modus, dan grafik poligon (Agung, 2012:67).

Analisis deskriptif kuantitatif merupakan suatu cara pengolahan data yang dilakukan dengan cara menyusun

secara sistematis ke dalam bentuk angka-angka atau presentase mengenai keadaan suatu objek yang diteliti sehingga diperoleh kesimpulan umum (Agung, 2012:67). Metode analisis deskriptif kuantitatif ini digunakan untuk menentukan tingkat tinggi rendahnya perkembangan motorik halus pada anak Taman Kanak-kanak dengan kegiatan meronce melalui metode demonstrasi. Tingkatan perkembangan motorik halus anak dapat ditentukan dengan membandingkan rata-rata persen ke dalam tabel kriteria sebagai berikut.

Tabel 3.6: Tabel Pedoman PAP Skala Lima Perkembangan Motorik Halus

\begin{tabular}{cc}
\hline Tingkat Penguasaan $(\%)$ & Kriteria Perkembangan Motorik Halus \\
\hline $90-100$ & Sangat Tinggi \\
$80-89$ & Tinggi \\
$65-79$ & Sedang \\
$55-64$ & Rendah \\
$0-54$ & Sangat Rendah
\end{tabular}

(Adaptasi Agung, 2010:10)

Sebagai suatu tolak ukur dalam penelitian ini akan ditetapkan indikator keberhasilan. Adapun indikator keberhasilan tersebut adalah sebagai berikut: 1)Terjadinya peningkatan perkembangan motorik halus sampai mencapai katagori tinggi, 2) Secara klasikal perkembangan motorik halus anak berkembang sesuai harapan mencapai $80 \%$.

\section{Hasil dan Pembahasan}

Data anak pada perkembangan motorik halus disajikan dalam bentuk tabel distribusi frekuensi, menghitung mean, median, modus, grafik poligon dan membandingkan rata-rata dengan model PAP skala lima. Nilai rata-rata (mean) yang diperoleh pada siklus $\mid \bar{X}=7,15$. Nilai modus pada siklus I diperoleh 6. Nilai median diperoleh 7.

Untuk menghitung tingkat perkembangan motorik halus anak dapat dihitung dengan membandingkan rata-rata persen (M\%) dengan kriteria PAP skala lima. Nilai M\% pada siklus I yang dikonversikan ke dalam PAP skala lima adalah 59,58\% berada pada kriteria rendah.

Nilai rata-rata (mean) yang diperoleh pada siklus II yaitu $\bar{X}=9,84$. Nilai modus pada siklus II diperoleh 11. Nilai median diperoleh 10. Nilai M\% pada siklus II yang dikonversikan ke dalam PAP skala lima adalah $82,01 \%$ berada pada kriteria tinggi.

Secara umum proses pembelajaran dengan menerapkan metode demonstrasi melalui kegiatan meronce untuk meningkatkan perkembangan motorik halus anak sudah berjalan dengan baik dan telah mencapai indikator keberhasilan. Hal ini terlihat dari adanya peningkatan rata-rata persentase $(\mathrm{M} \%)$ dari siklus I ke siklus II, sehingga penelitian ini cukup sampai disiklus II dan tidak dilanjutkan ke siklus berikutnya.

Berdasarkan hasil analisis data menggambarkan bahwa dengan menerapkan metode demonstrasi melalui kegiatan meronce untuk meningkatkan perkembangan motorik halus diperoleh rata-rata pada siklus I sebesar $59,58 \%$ dan rata-rata pada siklus II sebesar $82,01 \%$. Hal tersebut menunjukkan adanya peningkatan persentase rata-rata anak dari siklus I ke siklus II sebesar $22,43 \%$.

Penerapan metode demonstrasi dalam penelitian ini dibantu melalui kegiatan meronce ini akan membantu merangsang anak untuk mengembangkan motorik halusnya sehingga anak menjadi kreatif. Terjadinya peningkatan ini karena diterapkannya metode demonstrasi melalui 
kegiatan meronce, melalui kegiatan meronce, anak dapat melatih motorik halusnya. Sehingga terjadi peningkatan secara efektif pada perkembangan motorik halus anak. Dengan adanya kegiatan meronce ini maka kreativitas anak menjadi meningkat, dan anak mampu menghasilkan sebuah karya yang dapat menambah pengetahuan dan mengembangkan motorik halusnya.

Hasil ini didukung oleh pendapat Djamarah (2006:91) menyatakan:

1)Dapat membuat pengajaran menjadi lebih jelas dan lebih konkret, sehingga menghindari verbalisme (pemahaman secara kata-kata atau kalimat), 2) siswa lebih mudah memahami apa yang dipelajari, 3) proses pengajaran lebih menarik, 4) Siswa dirangsang untuk aktif mengamati, menyesuaikan antara teori dengan kenyataan, dan mencoba melakukannya sendiri.

Hasil penelitian ini juga sejalan dengan hasil penelitian yang dilakukan sebelumnya oleh Sugianingsih (2016) juga menerapkan penelitian yang berjudul penerapan metode demonstrasi berbantuan media playdough untuk meningkatkan ketrampilan motorik halus pada anak kelompok B terjadi peningkatan keterampilan motorik halus melalui penerapan metode demonstrasi berbantuan media playdough. Pada siklus I presentase sebesar $67,04 \%$ dan mengalami peningkatan pada siklus II menjadi $87,50 \%$ sehingga terjadi peningkatan ketrampilan motorik halus sebesar $20,46 \%$.

Dengan demikian dapat disimpulkan bahwa penerapan metode demonstrasi berbantuan media playdough dapat meningkatkan ketrampilan motorik halus anak kelompok B di TK Kumara Jaya Denpasar.

\section{Simpulan dan Saran}

Berdasarkan hasil analisis data, maka dapat disimpulkan bahwa terjadi peningkatan perkembangan motorik halus anak kelompok B1 TK Kartika VII-3 Singaraja setelah diterapkan metode demonstrasi melalui kegiatan meronce sebesar $22,43 \%$. Hal ini diketahui dari peningkatan rata-rata persentase anak siklus I sebesar $59,58 \%$ yang berada pada kategori rendah menjadi sebesar $82,01 \%$ pada siklus II yang berada pada katagori tinggi.

Berdasarkan simpulan di atas, saran-saran yang dapat diajukan adalah sebagai berikut.

1) Kepada siswa, agar dapat meningkatkan perkembangan motorik halus melalui metode demonstrasi melalui kegiatan meronce.

2) Kepada guru, untuk menambah wawasan anak tentang bahan alam, dalam proses pembelajaran dapat menggunakan metode demonstrasi melalui kegiatan meronce.

3) Kepada Kepala Sekolah, agar menyarankan kepada guru-guru untuk menerapkan metode demonstrasi melalui kegiatan meronce karena dapat meningkatkan perkembangan motorik halus anak.

4) Kepada peneliti lain yang ingin meningkatkan perkembangan motorik halus siswa dan tertarik dengan penelitian ini dapat menggunakan hasil penelitian sebagai bahan kajian untuk meneliti permasalahan dan dapat dijadikan suatu pembanding dalam penelitian berikutnya.

\section{Daftar Pustaka}

Agung, A. A. Gede. 2010. "Penelitian Tindakan Kelas (Teori dan Analisis Data dalam PTK)". Makalah disajikan dalam Wokshop Jurusan Pendidikan Guru Sekolah Dasar FIP Undiksha. Universitas Pendidikan Ganesha, Singaraja 27 September 2010.

------. 2012. Metodologi Penelitian Pendidikan. Singaraja: Universitas Pendidikan Ganesha.

Aqib, Zainal. 2013. Model-model, Media, dan Strategi Pembelajaran Kontektual (Inovatif). Bandung: Yrama Widya.

Arikunto, Suharsimi, dkk. 2006. Penelitian Tindakan Kelas. Jakarta: Bumi Aksara. 
Djamarah, Syaiful Bahri, dan Aswan Zain. 2006. Strategi Belajar Mengajar Edisi Revisi. Jakarta: PT RINEKA CIPTA.

Dimyati, Johni. 2013. Metodologi Penelitian Pendidikan dan Aplikasinya Pada Pendidikan Anak Usia Dini (PAUD). Jakarta: Kencana Prenada Media Group.

Iru, La. 2012. Analisis Penerapan Pendekatan, Metode, Strategi, dan Model-Model Pembelajaran. Yogyakarta: Multi Presindo.

Komalasari, Nyoman Wida. 2016. Penerapan Metode Demonstrasi Berlandaskan Teori Montessori Untuk Meningkatkan Keterampilan Motorik Halus Anak Kelompok A Di TK Santi Kumara Kelurahan Liligundi Kabupaten Buleleng Tahun Ajaran 2015/2016. Skripsi (tidak diterbitkan). Singaraja: Universitas Pendidikan Ganesha.

Latif, Mukhtar. 2013. Orientasi Baru Pendidikan Anak Usia Dini Teori dan Aplikasi. Jakarta: Kencana Prenada Media Group.

Samsudin. 2008. Pembelajaran Motorik di Taman Kanak-Kanak. Jakarta: Litera Prenada Media Group.

Sanjaya, Wina. 2008. Strategi Pembelajaran. Jakarta: Kencana Prenada Media Group.

Soetjiningsih, Christiana Hari. 2012. Perkembangan Anak Sejak Pembuahan Sampai dengan Kanak-kanak Akhir. Jakarta: Prenada Media Group.

Sugianingsih, Luh Komang. 2016. Penerapan Metode Demonstrasi Berbantuan Media Playdough Untuk Meningkatkan Perkembangan Motorik Halus Pada Anak Kelompok B Di TK Kumara Jaya Denpasar Tahun Pelajaran 2015/2016. Skripsi (tidak diterbitkan). Singaraja: Universitas Pendidikan Ganesha.

Sumanto. (2005). Pengembangan Kreativitas Seni Rupa Anak TK. Jakarta: Departemen Pendidikan Nasioanal.

Sumantri, MS. (2005). Model Pengembangan Ketrampilan Motorik Anak Usia Dini. Jakarta: Departemen Pendidikan Nasional.

Suyadi. 2010. Psikologi Belajar Pendidikan Anak Usia Dini. Yogyakarta: Pedagogia.

Undiksha. 2016. Pedoman Penulisan Skripsi dan Tugas Akhir. Singaraja: Undiksha Singaraja.

Yulianti, Dwi. 2010. Bermain Sambil Belajar Sains di Taman Kanak-kanak. Jakarta: Indeks. 